\title{
LATE ASSESSMENT OF TREATMENT OF NON-GONOCOCCAL URETHRITIS
}

\author{
Major R. N. T. THIN, M.D., M.R.C.P.(Ed.), R.A.M.C. * \\ Royal Herbert Hospital, Woolwich
}

SUMMARY : Fifty seven cases of non-gonococcal urethritis treated at Woolwich gave a cure rate of 82.4 per cent, and 102 cases treated at Singapore gave a cure rate of 71.6 per cent after three months observation. They were all treated with $250 \mathrm{mg}$ tetracycline four times daily for five days. These results are satisfactory compared with other reported series. In view of the tendency to relapse three months observation after treatment is recommended. In view of the variation in response to treatment in different series it is considered that individual venereologists should assess their own results bearing in mind that half the cases may spontaneously resolve.

\section{Introduction}

In 1964 (a) King observed that the tetracycline group of drugs were the most effective agents for treating non-gonococcal urethritis. Since then many more cases of this condition have been treated with tetracycline. According to most published reports $250 \mathrm{mg}$ four times daily for five to seven days gives a cure rate of 70 to 80 per cent. However criteria for cure and duration of follow-up after treatment have varied, and in some instances have not been clearly defined. Recently Fowler (1970) showed that after three months' observation following $250 \mathrm{mg}$ tetracycline four times daily for four days the cure rate fell to 55 per cent, only 10 per cent better than cases given a placebo. John (1971) also reported a 55 per cent cure rate three months after $500 \mathrm{mg}$ oxytetracycline three times daily for five days.

Cases of non-gonococcal urethritis among soldiers in the British Army are usually treated with a five day course of tetracycline; the object of this paper is to report the results obtained when cases were followed for three months after treatment.

\section{Methods}

Cases attending the Royal Herbert Hospital at Woolwich in 1969, and the British Military Hospital at Singapore in 1970 were studied. Only patients who completed three months observation under personal supervision are included.

The diagnosis of non-gonococcal urethritis was based on finding a sexually acquired urethral discharge containing pus cells but the negative results in Gram stained smears and cultures. When Candida albicans and Trichomonas vaginalis were found the cases were excluded.

All cases received $250 \mathrm{mg}$ tetracycline four times daily for five days and were seen $1,2,4,8$, and 12 weeks after starting treatment. Criteria for cure were absence of urethral discharge and macroscopically clear specimens in the two glass test after urine had been held for at least four hours. 


\section{Results}

Fifty seven cases seen at Woolwich were included. Two weeks after treatment 52 (91.2 per cent) were considered cured and at three months 47 (82.4 per cent) were cured.

One hundred and two cases were seen at Singapore. At two weeks 98 (96.1 per cent) were considered cured and at three months 73 ( 71.6 per cent) were cured. These results are shown in greater detail in Table $I$ omitting the findings at one week after treatment as the patient had only just finished treatment.

Table I

Detailed results compared with other series

\begin{tabular}{|c|c|c|c|c|c|c|c|c|c|}
\hline \multirow{3}{*}{ Series and Therapy } & \multirow{3}{*}{ Cases } & \multicolumn{6}{|c|}{ Number cured } & \multirow{2}{*}{\multicolumn{2}{|c|}{ at 12 weeks }} \\
\hline & & \multicolumn{2}{|c|}{ at 2 weeks } & \multicolumn{2}{|c|}{ at 4 weeks } & \multicolumn{2}{|c|}{ at 8 weeks } & & \\
\hline & & No. & per cent & No. & per cent & No. & per cent & No: & per cent \\
\hline $\begin{array}{c}\text { Woolwich } 1969 \\
5 \mathrm{~g} \text { in } 5 \text { days }\end{array}$ & 57 & 52 & 91.2 & 48 & 84.2 & 48 & 84.2 & 47 & 82.4 \\
\hline $\begin{array}{r}\text { Singapore } 1970 \\
5 \mathrm{~g} \text { in } 5 \text { days }\end{array}$ & 102 & 98 & 96.1 & 87 & 85.3 & 76 & 74.5 & 73 & 71.6 \\
\hline $\begin{array}{l}\text { Fowler (1970) } \\
\quad 4 \mathrm{~g} \text { in } 4 \text { days }\end{array}$ & 161 & 116 & 72.0 & 108 & 67.1 & 93 & 57.7 & 89 & 55.3 \\
\hline $\begin{array}{l}\text { John }(1971) \\
7.5 \mathrm{~g} \text { in } 5 \text { days }\end{array}$ & 132 & & & 75 & 56.8 & 73 & 55.3 & 73 & 55.3 \\
\hline $\begin{array}{l}\text { John }(1971) \\
20 \mathrm{~g} \text { in } 10 \text { days }\end{array}$ & 169 & & . & 151 & 89.3 & 138 & 81.6 & 122 & 72.2 \\
\hline $\begin{array}{l}\text { John }(1971) \\
21 \mathrm{~g} \text { in } 21 \text { days }\end{array}$ & 200 & & . & 191 & 95.5 & 181 & 90.5 & 175 & 87.5 \\
\hline
\end{tabular}

Note: In Fowler's series the number of cures at 8 weeks is approximate.

The results of careful questioning indicated that at Woolwich the 10 cases with recurrence of urethritis comprised 8 with relapse and 2 with reinfection. At Singapore there appeared to be 16 cases who relapsed and 13 with reinfection.

\section{Discussion}

The cure rates at three months were 82.4 per cent at Woolwich and 71.6 per cent at Singapore, and Table I illustrates how cure rates fell as follow-up continued. These are better than Fowler's (1970) findings and the results John (1971) reported using $500 \mathrm{mg}$ oxytetracycline three times daily for five days. The results in Singapore resemble those John (1971) obtained after $500 \mathrm{mg}$ oxytetracycline four times daily for ten days; twice the daily dose for twice as long as the regimes used in Singapore. John (1971) reported the best results using $250 \mathrm{mg}$ oxytetracycline four times daily for 21 days (see table).

The cause of non-gonococcal urethritis has not been investigated in Singapore with all the techniques currently available. The present findings indicate that it behaves in 
the same way there as in Britain, and studies in nearby regions support this view (Gartman and Leibovitz 1955, and Holmes, Johnson and Lloyd 1967).

King (1964b) reviewed a number of studies of non-gonococcal urethritis in which only a placebo had been prescribed. The condition had resolved over two months in 50 to 70 per cent of cases. Csonka (1965) also noted that about 50 per cent of cases may spontaneously resolve. It is worth emphasising that in most of these reports resolution was gradual. Cases treated with tetracyclines usually improve rapidly though relapse may be more common than in patients given a placebo (Morton and Read 1957).

Csonka (1965) recommended short term assessment after treatment since many factors affect late recurrence. As shown here proportions of relapse and reinfection contributing to recurrence vary. However late relapse is a well known feature of this condition and in Singapore accounted for half the cases with recurrence. The table shows how short term assessment may give a false impression of the efficacy of treatment. At a time when the incidence of non-gonococcal urethritis is rising it is important to observe treated cases for a reasonably long period such as three months to ensure a satisfactory outcome and to minimise spread of infection by inadequately treated patients. Furthermore, in view of the variable response to treatment which has been reported, all venereologists should examine their own results bearing in mind that up to 50 per cent of cases may spontaneously resolve.

\section{REFERENCES}

CsonKa, G. (1965). Brit. J. vener. Dis. 41, 1.

FOWLER, W. (1970). Brit. J. vener. Dis. 46, 464.

GARTMAN, E. and Leibovitz, A. (1955). Brit.J. vener. Dis. 31, 92.

Holmes, K. K. Johnson, D. W. and Floyd, T. M. (1967). J. Amer. med. Ass. 202, 474.

JoHN, J. (1971). Brit. J. vener. Dis. 47, 266.

KING, A. (1964a). Recent Advances in Venereology. J. \& A. Churchill, London. P. 384.

KING, A. (1964b). Recent Advances in Venereology. J. \& A. Churchill. London. P. 379.

Morton, R. S. and READ, L. (1957). Brit. J. vener Dis. 33, 223. 